\title{
Implication of Conversation in Interactive Dialogue of Public Eyes in Trans 7
}

\author{
Aziz Rio Kausar \\ Institut Agama Islam Negeri Bengkulu \\ azizriokausar95 .com \\ Kasmantoni \\ Institut Agama Islam Negeri Bengkulu \\ Kasmantoni1975@gnail.com \\ Bustomi \\ Institut Agama Islam Negeri Bengkulu \\ Bustomi.Hasan@iainbengkulu.co.id
}

\begin{abstract}
The phenomenon of implicature is also found in many television programs, such as talk shows, comedy programs, and programs with the concept of motivating listeners or viewers. This research is only about the implicatures of conversation in the interactive dialogue of mata najwa with public officials at Trans7. The problem in this research is how is the function of conversational implicature in the interactive dialogue of Mata Najwa in Trans7. The goal to be achieved in this study is to describe how the function of conversational implicatures in the interactive dialogue between Mata Najwa and Public Officials in Trans7. This research is a research with descriptive qualitative method. Data collection is done by recording and note-taking techniques. Data analysis was carried out through several procedures: (1) data reduction (data selection and data coding), (2) data presentation, and (3) conclusion drawing and data verification. Based on the results of data analysis and discussion, the conclusion of this study the researchers found the function of conversational implicatures in the interactive dialogue of Mata Najwa Trans7 with public officials. The four implicature functions in the form of speech acts are the conversational implicature function in representative speech, the conversational implicature function in commissive speech, the conversational implicature function in directive speech, and conversational implicature in expressive speech. In addition, the researcher also found the meanings of conversational implicatures contained in Mata Najwa Trans7's interactive dialogue with public officials, there were (17) seventeen implicature intentions. These purposes include: 1) stating, 2) explaining, 3) speculating, 4) showing, 5) informing, 6) admitting, 7) giving testimony, 8) reporting, 9) refusing, 10) inviting, 11) urged, 12) suggested, 13) forbade, 14) pleaded, 15) criticized, 16) blamed, 17) insinuated. The most common conversational implicatures in Mata Najwa Trans7's interactive dialogue are conversational implicatures in the representative speech function with a total of 26 utterances. The meaning that appears the most is the intention ( state ).
\end{abstract}

Keywords : Conversational Implicature, Interactive Dialogue

\section{A. Introduction}

Language is the sounds issued by the human speech apparatus and must be meaningful (Pateda, 1994: 5). Language has an important function for humans, especially the communicative function. In everyday life, humans always use language in various forms to 
meet their needs. By communicating, humans can fulfill their desires as social beings who are interconnected to express their thoughts and opinions and work together .

According to Keraf (1997: 1) language is a means of communication between community members in the form of sound symbols produced by human speech tools. The science that studies the nature and characteristics of language is called linguistics. Linguistics is a science that takes language as an object of study, therefore it is very helpful in studying the elements of language and the relationships of these elements in fulfilling their function as a tool for human relations (Chaer, 2004: 6).

One of the language studies that is able to accommodate aspects outside of language is the study of linguistics pragmatics. Yule (2006: 3) pragmatics is the study of meaning conveyed by speakers (writers) and interpreted by listeners (or readers). The study of language using pragmatics certainly involves aspects outside of language that also give meaning to a communication.

Speakers and listeners in conversation generally work together, the cooperation in question is in the form of a common background of knowledge. According to Wijana (1996: 86) each participant is equally aware that there are rules that govern his actions, use of language, and interpretations of the actions and words of his interlocutor. The conversation that happens often contain intentions more tire yak than must admit that dar's own words. Such conditions cause conversational implicatures to be the right role to examine aspects outside the use of language. According to Brown and Yule (2006: 31) implicature is what the speaker might mean, suggest, or mean that is different from what the speaker actually said. Implicature is considered important to be studied further, especially conversational implicature. There are five general types of implicature functions, namely, declaration, representative, expressive, directive, and commissive (Yule, 2006: 92-94).

The phenomenon of implicature is also found in many television programs, such as talk shows, comedy, and programs with the concept of motivating listeners or viewers. The use of language that contains implicatures can make it difficult for listeners or viewers if they do not have sufficient knowledge to interpret the language. Involving speech situations alone is not enough for listeners or viewers to capture the meaning of language forms that contain implicatures. Mata Najwa is one of the private television programs enjoyed by millions of Indonesians. Mata Najwa is an interactive dialogue program that is packaged in an interesting way, highlighting social phenomena that are currently being discussed in the community by presenting the speakers directly.

This study will examine the function of conversational implicatures in Mata Najwa Trans 7 interactive dialogue with public officials. The author chose the Mata Najwa interactive Dialogue program which was guided by a senior journalist named Najwa Shihab because Najwa is famous for being adept at giving critical and sharp questions to her 
sources which are sometimes difficult to answer. The question asked by Najwa is not always conveyed explicitly in the speech, but hidden behind the speech itself, and vice versa .

\section{B. Research Method}

Metode qualitative descriptive. Qualitative method is a research procedure that produces descriptive data in the form of written or spoken words from people and observable behavior (Bogdan in Moleong, 2005: 3). This is a descriptive study because the data obtained can not be put in the form of numbers or statistics, researchers an is explained picture of the situation being investigated. This research method is used to describe the function of conversational implicatures in Mata Najwa's interactive dialogue with public officials at Trans 7 . The research instruments are tools or facilities used by researchers as a guide in conducting research so that the work is easier. This research uses data collection instruments and data analysis guiding instruments. Data collection instruments in the form of recordings and notes .

The data analysis technique is a continuation of the data collection that has been done. The steps are as follows: 1) listening and recording the utterances in the Mata Najwa interactive dialogue conversation on Trans7, (2) classifying and clarifying the function of conversational implicatures in the Mata Najwa interactive dialogue on Trans7, (3) each classification group then the data is analyzed further. further, (4) describe the function of conversational implicature in the interactive dialogue of Mata Najwa in Trans7 , (5) interpret the function of implicature in the language of the interactive dialogue of Mata Najwa in Trans7, (6) draw conclusions about the implicature of interactive conversation of Mata Najwa in Trans7.

\section{Results and Discussion \\ 1. Results}

The results of the study found four functions of conversational implicatures based on speech acts, namely, 26 representative implicature speech (statement of a fact, affirmation, conclusion, and description), 4 commissive implicature speech (promise, threat, rejection), 15 directive implicature (ordering), and 13 expressive implicatures (apologizing, thanking, congratulating, praising, and criticizing) in Mata Najwa's interactive dialogue on Trans7 with 
public officials. In addition, seventeen conversational implicatures were also found based on speech act theory. The seventeen pragmatic meanings are 10 stating, 1 explaining, 4 speculating, 7 indicating, 1 informing, 1 admitting, 1 testifying, 1 reporting, 4 rejecting, 1 inviting, 3 urging, 8 suggesting, 2 forbidding, 1 requesting, 6 criticize, I blame, and 6 satirize.

This research found four functions such as speech acts conversational implicatures. The four forms of implicature are: representative, commissive, directive, and expressive. The following describes the implicature functions as follows:

\section{Representative Function}

Yule (2006: 92) says that representative is a type of speech act that states what the speaker believes in the case or not, in the sense of a representative speech act in the form of a statement of a fact, affirmation, conclusion, and description. Speech acts that function to determine or explain something as it is. These speech acts such as reporting, stating, informing, explaining, defending, and so on. Based on the data collected, the researcher found the function of the implicature in the form of a representative speech act. Consider the following data as an example of representative implicature.

Najwa: "Mrs. Noor, why do you want to come forward to replace you as regent?"

Noor: "There is a struggle here, because I am the only woman in Kalimantan who wants to run as a candidate for regent. Previously, I was also the first woman in South Kalimantan to become chairman of the DPRD for the province of South Kalimantan with the most votes of almost 50 thousand plus the Golkar vote.

Context : Mata Najwa invited a guest star for a candidate for regent from South Kalimantan named Ibu Noor. Najwa interviewed Noor's mother about the reason why she ran to run as a candidate for regent, considering that the status of Noor's mother's husband was a former regent of South Kalimantan. Mrs. Noor is running to become the first female regent candidate to represent South Kalimantan to pass the election process.

\section{Commissive Function}

Yule (2006:94) says that commissive is a speech act that is understood by the speaker to bind himself to future actions. This speech act states what the speaker intended. This speech act can be; promises, threats, refusals, pledges. Based on this research, the researcher found 4 speech data containing implicatures in the form of commissives. Consider the following data as an example that contains commissive implicatures.

Najwa: "The fact that you are the son of the governor has no effect?" 
Karolin: "There is a governor's son who is also running for office and does not have the support of all political parties. So, I don't think there's only one factor. Episode "Drama Struggle for Power" (V1/DT.7)

Context: The story takes place at night in the Mata Najwa Trans7 studio. The atmosphere is relaxed and calm. Mata Najwa brought Karolin Margaret as the candidate for regent of Landak, West Kalimantan. Najwa asked Karolin's mother about the influence her father, who had served as governor of Landak, had on her nomination as candidate for regent of Landak. According to Karolin, being the son of a governor is not a guarantee of getting support from political parties.

\section{Directive Function}

According to Yule (2006: 93) directives are types of speech acts used by speakers to tell others to do something. In this study, the researcher found 15 speech data containing directive form implicatures . Consider the following data as an example containing directive implicatures. Najwa: "It's a mess because of this corruption, sir?"

I Gede: "That's what happened, so don't be corrupt anymore" (Episode "Ahok Djarot's Kick). (V3/DT.5)

Context: The story takes place at night in the Trans7 studio. In a relaxed atmosphere, Najwa interviewed Pak Gede about the condition of the Ministry of Home Affairs after two members of the Ministry of Home Affairs became suspects in the E-KTP corruption. Pak Gede told about the chaotic situation of the Ministry of Home Affairs and the mental breakdown after the corruption case of E-KTP funds.

\section{Expressive Functions}

Expressive is a type of speech act that states something that is felt by the speaker (Yule, 2006: 93). Expressive speech acts aim to express feelings and attitudes. These speech acts are in the form of apologizing, thanking, congratulating, praising, and criticizing. Consider the following data as an example containing directive implicatures.

Najwa: "So it means that the various dynamics that occur will not change your plans if you are elected?"

Ahok: "Oh no, I have already confirmed, the flat is ready. People used to ask me, for example, the KPU came to me in the past, "Sir, is it okay if you don't relocate before the election, sir?" I said I couldn't because I wanted to catch up with the flood. If the rusu is ready, I will move it. After all, they can choose in the flats, so it's a little hard work. So, if we both just want to be governors, we'll end up lying, we don't evicte, we don't normalize (Episode "Ahok Djarot Kick"). (V2/DT.11)

Context: Speech occurs at night. The atmosphere of the speech is relaxed and calm, the condition of the speech taking place in the Mata Najwa Trans7 studio. Najwa interviewed Pak Ahok 
whether he would continue his project when he was elected governor of Jakarta again. Ahok will continue his project regardless of the conditions. Ahok's statement came about because he heard the statement of candidate pair number 3 who said that they would not evicte the houses of Jakarta residents who lived on the banks of the river but would only move them.

\section{B. Discussion}

The research entitled Conversational Implicature in Mata Najwa Metro TV's Interactive Dialogue with Public Officials aims to describe the function, and purpose of conversational implicature. The target in this research is the speech of Najwa and public officials when conducting an interactive dialogue in the Mata Najwa Trans7 event .

The researcher raised the conversational implicatures spoken by Najwa and public officials as a research topic because the research is still rarely done. In addition, the researcher conducted an implicature study of Najwa's and public officials' conversations because they saw the fact that the questions asked by Najwa Shihab had hidden intentions behind these questions, on the other hand, an official in answering questions was sometimes convoluted and had hidden intentions behind the answers. In addition, Mata Najwa is one of the interactive dialogue programs on television that has received the most appreciation from the public, while not all Indonesians have a high educational background. These things are taken into consideration by researchers before conducting research on conversational implicatures by Najwa and public officials. The researcher used data collection techniques in the form of a listening method with a note-taking technique.

In Mata Najwa Trans7's interactive dialogue, researcher found many kinds of information, both statements, explanations, speculations, orders, criticisms, and so on. Based on the data that has been collected, utterances with the intention of stating the most are found in the interactive dialogue of Mata Najwa. The analytical knife to examine the utterances that contain conversational implicatures and find the meanings of implicatures in the interactive dialogue of Mata Najwa, the researcher uses the theory of Searle and Yule.

One of the scopes of pragmatics is conversational implicature, conversational implicature cannot be separated from the role of context. As stated by Levinson (in Rahardi, 2005: 48) that pragmatics is the study of language which studies the relation of language with its 
context. In Mata Najwa's interactive dialogue, to understand the subject being discussed, a participant must understand each context of the utterances.

In this study, researchers found four forms of implicature in the form of speech acts, namely conversational implicatures in representative, commissive, directive, and expressive speech. In addition, the researchers found seventeen conversational implicatures contained in the Mata Najwa Trans7 interactive dialogue program .

According to Yule (2006: 92) representative speech acts are types of speech acts that state what the speaker believes in the case or not, in the sense of representative speech acts in the form of statements about a fact, affirmations, conclusions, and descriptions. Another understanding put forward by Dardjowidjojo (2010), that a representative speech act is only a statement about something, so what we need to do is collect the content of the proposition and understand which is old information and which is new. According to the researcher, representative speech acts are speech acts that function to describe information so that the truth value can be accounted for by the speaker. In his research, the researcher found 26 (twenty six) utterances containing representative conversational implicatures.

Commissive implicature is a form of implicature based on the theory of commissive speech acts. According to Yule (2006: 94), commissive speech acts are speech acts that are understood by speakers to bind themselves to future actions. According to Dardjowidjojo (2010: 95) commissive speech acts can actually be considered the same as directive speech acts, only the direction is different. In directive utterances the listener is expected to do something. In commissive speech acts, the "command" is directed to the speaker himself. According to researchers, commissive speech acts are speech acts that involve themselves in future actions. In this study, it is called the form of commissive implicature.

In this study, the researcher found 4 (four) utterances containing conversational implicatures in the Mata Najwa Interactive dialogue. In the four speech implicature functions, the researcher found one kind of speech intent included in the commissive implicature function, namely the intention of rejecting. This intention supports the understanding of the function of commissive implicature, which is a speech act that is understood by the speaker to bind himself to future actions. The intention of refusing is used by speakers in the interactive dialogue of Mata 
Najwa to refute an opinion expressed by the interlocutor to the speaker. According to Ibrahim (1993) the directive expresses the speaker's attitude towards the actions that will be carried out by the speech partner, for example asking, begging, inviting, asking, rule, and advise. According to Yule (2006: 93) directives are types of speech acts used by speakers to tell others to do something. So, a directive speech act is a speech act that is used by the speaker for the action that the speech partner will take to do something. Dardjowidjojo (2010: 101) states that directive speech acts can be divided into three smaller groups, namely questions with yes/no/not/no answers, questions that require which/(si/why) answers, and orders to do something. In Mata Najwa's interactive dialogue, the researcher found 15 (fifteen) utterances containing the function of directive conversational implicatures. The fifteen intentions contain 5 (five) speech intentions which are included in the directive implicature function. The five purposes are, 6 to invite, 3 to urge, 8 to suggest, 2 to prohibit, and 1 to request.

Based on the understanding stated above, it can be concluded that the five purposes support the notion of the directive implicature function. The five purposes of the directive function that are most commonly found are utterances with the intention of suggesting. The purpose of suggesting is used by speakers to convey suggestions, to give suggestions as described in the KBBI (2008: 1226). recommend.

Expressive is a type of speech act that states something that is felt by the speaker (Yule, 2006: 93). In addition, Dardjowidjojo (2010: 106) says that expressive speech acts state a person's psychological state, so their implementation is not in the form of actions, especially physical actions. According to the researcher, expressive speech acts are speech acts that function to express the psychological feelings of the speaker himself and without involving physical actions from either the speaker or his interlocutor. In this research, it is called expressive implicature.

In Mata Najwa's interactive dialogue, the researcher found 13 (thirteen) speech functions that contain expressive conversational implicatures. The thirteen functions contain three speech intentions which indicate that these intentions are in the expressive implicature function. The three purposes are, 6 to criticize, 1 to blame, and 6 to insinuate. The most common expressive utterances found are criticizing and sarcastic purposes. 
Based on these findings, it can be concluded that the three purposes support the understanding of the expressive implicature function, which is an utterance used by speakers to express feelings to their interlocutors.

\section{Conclusion}

Based on the results of data analysis and discussion, the conclusion of this study found the function of conversational implicatures in Mata Najwa's interactive dialogue with public officials at Trans7. The four implicature functions in the form of speech acts are the conversational implicature function in representative speech, the conversational implicature function in commissive speech, the conversational implicature function in directive speech, and conversational implicature in expressive speech. Interactive Mata Najwa Trans7 with public officials, there are (17) seventeen implicature intentions. These purposes include: 1) stating, 2) explaining, 3) speculating, 4) showing, 5) informing, 6) admitting, 7) giving testimony, 8) reporting, 9) refusing, 10) inviting, 11) urged, 12) suggested, 13) forbade, 14) pleaded, 15) criticized, 16) blamed, 17) insinuated. The most common conversational implicatures that appear in the interactive dialogue of Mata Najwa Trans7 are conversational implicatures in the representative speech function with (Declaring) a total of 26 utterances.

\section{References}

Arikunto, S. (2010). Research Procedures A Practical Approach . Jakarta: Reinika Cipta.

Chaer, A. (2004). General Linguistics . Jakarta: Rineka Cipta.

Hamid, H. (2011). Analysis of Pragmatic Discourse. Bandung: Space.

Handayani, C. Sumawarti, and Suhita, R. (2014). Conversational Implicatures in the Mata Najwa Talk Show on Metro TV. Vol. 2. No. 3. Retrieved January 16, 2017.

Hariyono, A. (2014). Conversational Implicatures in Advertising Drug Products on Television. Thesis. Yogyakarta: Faculty of Languages and Arts. Yogyakarta State University.

Ibrahim, A. \& Syukur. (1993). Study of Speech Acts. Surabaya: National effort.

Keraf, G. (1997). Indonesian Language Reference Grammar. Jakarta: Gramedia Widia Sarana Indonesia.

Lubis. (2006). Discourse Analysis. Jakarta: Gramedia.

Moloeng, LJ. (2005). Qualitative Research Methodology. Bandung: Rosdakarya Youth. 
Muhammad. (2014). Language Research Methods. AR-Ruza Media:Yogyakarta.

Nadar, FX. (2009). Pragmatics \& Pragmatic Research. Yogyakarta: Graha Ilmu.

Pateda, M. (1994). Sociolinguistics . Bandung: Space.

Rahardi, K. (2005). Pragmatics of Indonesian Imperative Politeness. Jakarta: Erlangga.

Rahman, C. (2016). Political Advertisements of Presidential and Vice Presidential Candidates in 2014: Pragmatic Analysis. Surabaya.

Rani, A. et al. (2006). Discourse Analysis. Malang: Bayumedia Publishing

Rohmadi, M. (2010). Pragmatics Theory and Analysis. Yogyakarta: Lingkar Media Jogja.

Rosidi, I. (2009). Writing. . . No need to worry? . Bandung: Kanisius.

Sudarmawanti. (2008). Language and Literature. Jakarta: Ministry of National Education Book Center.

Sudaryanto. (1993). Methods and Various Data Collection Techniques . Yogyakarta: Gajah Mada University Press

Suyono. (1990). Pragmatics Fundamentals and Teaching .Malang: asih Asah asuh Foundation (YA 3 Malang)

Wijana, IDP. (1996). Fundamentals of Pragmatics. Yogyakarta: Offset Student.

Yule, G. (2006). Pragmatics. Yogyakarta: Student Library.

Zamzani. (2007). Sociolinguistic Studies. Yogyakarta: Cipta Pustaka.

Ratna, N.K. (2012). Theory, Methods, and Techniques of Literary Research. Yogyakarta: Student Library.

Setiadi, etal.(2016). Basic Socio-Cultural Sciences. Jakarta : PT Fajar Interpratama Mandiri.

Sumardjo, J., \& Saini. KM. (2010). Literary Appreciation. Jakarta: Gramedia Pustaka Utama. https://brainly.co.id/task/8956783 